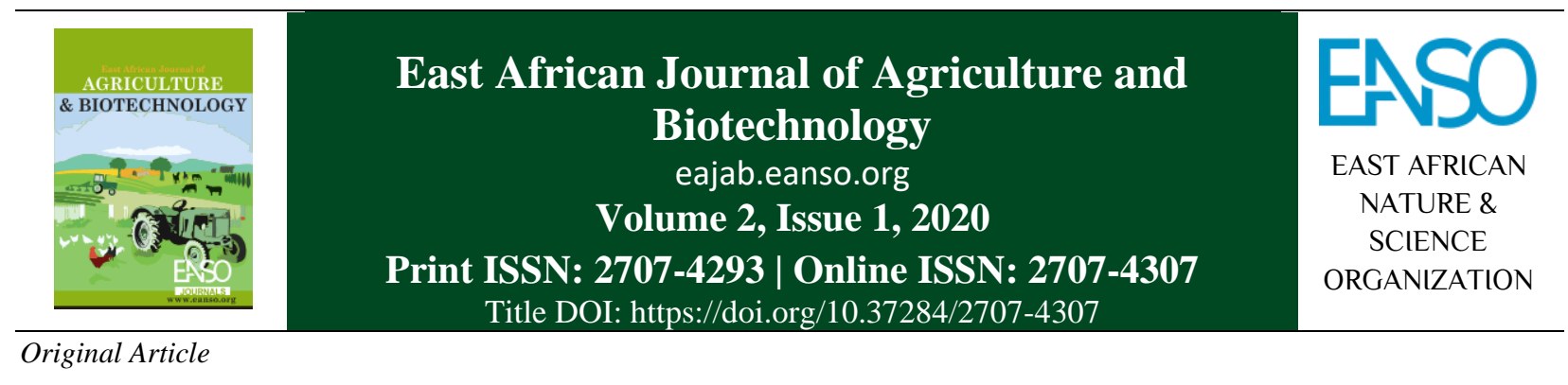

\title{
Factor Influencing Adaptation Choices Employed by Farmers Against Climate Change to Improve Rice Yield in Bugarama Wetland in Rwanda
}

\author{
Esther Nyirandorimana ${ }^{1 *}$, Dr. Ezekiel Ndunda ${ }^{1} \&$ Dr. John Muriuki ${ }^{1}$ \\ ${ }^{1}$ Kenyatta University, P. O. Box 43844 - 00100, Nairobi, Kenya. \\ *Author for Correspondence email: nyirandorimanaesther@gmail.com
}

Article DOI: https://doi.org/10.37284/eajab.2.1.137

Date Published: ABSTRACT

14 Apr 2020 The changing climate poses a great challenge to many wetlands productivity worldwide. Rice production in wetlands is a major source of livelihood in

Keywords: developing countries such as Rwanda. This study aimed at determining the factors

Climate Change,

Perception,

Adaptation,

Heckman Two-Step

Model,

Bugarama Wetland. influencing adaptation methods when farmers perceive the changing climate at Bugarama Wetland Rice Scheme in Rwanda. A descriptive research design was used by this study, whereby quantitative and qualitative data was collected. The analysis was based on data collected from 300 selected farmers using systematic random sampling method. We employed descriptive statistics to assess how farmers perceive the effects of climate change and descriptively measured the new adaptation methods used by farmers in Bugarama to increase their yields. The study adopted Heckman two-step model to determine factors that influence adaptation choices, this analysis procedurally required farmers' knowledge of perception that makes them respond to the effects of changes in climatic conditions by the use of new adaptation methods. The results deduced that level of education $(\mathrm{p}=0.019)$, extension access $(\mathrm{p}=0.001)$, market distance $(\mathrm{p}=0.002)$ and rice income $(\mathrm{p}<0.001)$ had a probability of influencing farmers perceptions about climate change thus need to adapt. Based on the outcome model, results showed that extension access ( $\mathrm{p}<$ $0.001)$, household size $(\mathrm{p}=0.098)$, market distance $(\mathrm{p}=0.047)$, rice income $(\mathrm{p}$ $=0.032)$, farmers-to-farmers contact $(\mathrm{p}<0.001)$ and effects of climate change on rice $(\mathrm{p}=0.038)$ had a greater probability of influencing farmers choice of adaptation method used to improve rice yields. To conclude, the study found that access to informational facilities and rice income, influenced farmers' perceptions while extension access, rice income, market distance, farmers-to-farmers contact and effects of climate change on rice yield strongly had a probability of determining farmers' choice of adaptation. This study recommends that the Rwandan 
government and local administrators need to develop a strategy that would allow farmers to access information facilities about new technology so as to adapt to the effects of climate change thus improve their rice yields.

\section{APA CITATION}

Nyirandorimana, E., Ndunda, E., \& Muriuki, J. (2020). Factor Influencing Adaptation Choices Employed by Farmers Against Climate Change to Improve Rice Yield in Bugarama Wetland in Rwanda. East African Journal of Agriculture and Biotechnology, 2(1), 12-22. https://doi.org/10.37284/eajab.2.1.137

\section{CHICAGO CITATION}

Nyirandorimana, Esther, Ezekiel Ndunda, and John Muriuki. 2020. "Factor Influencing Adaptation Choices Employed by Farmers Against Climate Change to Improve Rice Yield in Bugarama Wetland in Rwanda". East African Journal of Agriculture and Biotechnology 2 (1), 12-22. https://doi.org/10.37284/eajab.2.1.137.

\section{HARVARD CITATION}

Nyirandorimana, E., Ndunda, E. and Muriuki, J. (2020) "Factor Influencing Adaptation Choices Employed by Farmers Against Climate Change to Improve Rice Yield in Bugarama Wetland in Rwanda", East African Journal of Agriculture and Biotechnology, 2(1), pp. 12-22. doi: 10.37284/eajab.2.1.137.

\section{IEEE CITATION}

E. Nyirandorimana, E. Ndunda, and J. Muriuki, "Factor Influencing Adaptation Choices Employed by Farmers Against Climate Change to Improve Rice Yield in Bugarama Wetland in Rwanda", EAJAB, vol. 2, no. 1, pp. 12-22, Apr. 2020.

\section{MLA CITATION}

Nyirandorimana, Esther, Ezekiel Ndunda, and John Muriuki. "Factor Influencing Adaptation Choices Employed by Farmers Against Climate Change to Improve Rice Yield in Bugarama Wetland in Rwanda". East African Journal of Agriculture and Biotechnology, Vol. 2, no. 1, Apr. 2020, pp. 12-22, doi:10.37284/eajab.2.1.137.

\section{INTRODUCTION}

Lowland and marshy areas are the most potential yields of agriculture. However, changing climate has destroyed the marshland fertility, consequently reducing crops yields. For example, some studies which had been done in developed nations generally showed great negative impacts on $(-60$, $70 \%$ ) or a total failure of crop yields (Celia \& Bancolita, 2014). However, it is reported that most of the countries in Africa are greatly experiencing the impacts of climate change on agricultural produce (Gupta et al., 2019; Lamboll et al., 2017; Mikova et al., 2015; Moshi \& Isinika, 2016). The validation of these studies posits that more studies are required in many different parts of Africa to specifically diagnose adaptation choices needed to improve agricultural yields. Empirically, climate change and its seasonal variability are of great significance to smallholder farmers, thus threatening their daily livelihoods (Belay et al., 2017; Mashizha, 2019). Rwanda is one of the most identified vulnerable countries in terms of climatic changes. Moreover, rice farming has been playing a vital role in the socio-economic welfare of the people due to Rwanda's rich alluvial soils that are suitable for rice farming (Garcia, 2015; Mikova et al., 2015). This has caused farmers from Bugarama to have different perceptions on how to curb the effects of climate change while increasing their rice yield. The impacts of climate change have led to farmers and researchers to identify some coping mechanism that would maximize the yield of crops in agriculture. These adaptation options are employed by farmers depending on their socioeconomic capacity. The new coping technology adopted always assumed to improve the farm produce in the midst of changing climate effects. However, the choice of adopted methods depends on farmers' level of knowledge about climate and the prevailing perception (Mashizha, 2019). There are many studies which have been done on factors determining the adaption options to be employed against climate change to improve yields (Ali \& Erenstein, 2017; Amare \& Simane, 2017; Asrat \& Simane, 2018; Deressa et al.,2009; Ferdushi et al., 2019; Mabuku et al., 2019; Ojo \& Baiyegunhi, 2019) which mainly described determinants of the choices. This has limited the contribution of adaptation strategies and therefore there is an urgency to strengthen new measures that can be 
employed by smallholder farmers of Bugarama. The understanding of factors influencing farmers decision is first perceived by the knowledge then farmers adapt depending on their socio-economic status (Asrat \& Simane, 2018). The adoption of a particular choice is a vital insight into the productivity in the farm. In particular, Bugarama wetland has been affected by climatic conditions that have been changing (Shumbusho, 2009). This study aims at bridging the gap between factors influencing adaptation methods and choices that are made by the farmers in Bugarama rice production so as to improve their yields. This study has a significant contribution to the farmers of Bugarama because it can help them make better decisions when adapting mitigations against climate change. It can also help policymakers gain perspective on the adaptation methods for rice farming and generally add literature to the scientific discipline.

\section{RESEARCH METHODOLOGY}

\section{Area of Study}

Bugarama rice scheme is located at $2^{\circ} 41^{\prime} 50^{\prime \prime} \mathrm{S}$ $29^{\circ} 00^{\prime} 30^{\prime \prime} \mathrm{E}$ of Rusizi Districts in Rwanda. It is about $307 \mathrm{~km}$ Southwest from Kigali, the capital city of Rwanda. Bugarama covers $24 \mathrm{~km}^{2}$ with a population density of $1244 / \mathrm{km}^{2}$. This zone is identified as highland at $1200 \mathrm{~m}$ above sea level. Soils are transitional and characterized by an intermediary between upland and lowland which are marshy, alluvial connected to the lowland due to material deposits. However, the colloidal concentration at the upland is due to better drainage. The main soil type at Bugarama is generally alluvial soils, characterized by fluvisols with sandy loam texture.

Figure 1: Area covered by Bugarama wetland, Rwanda

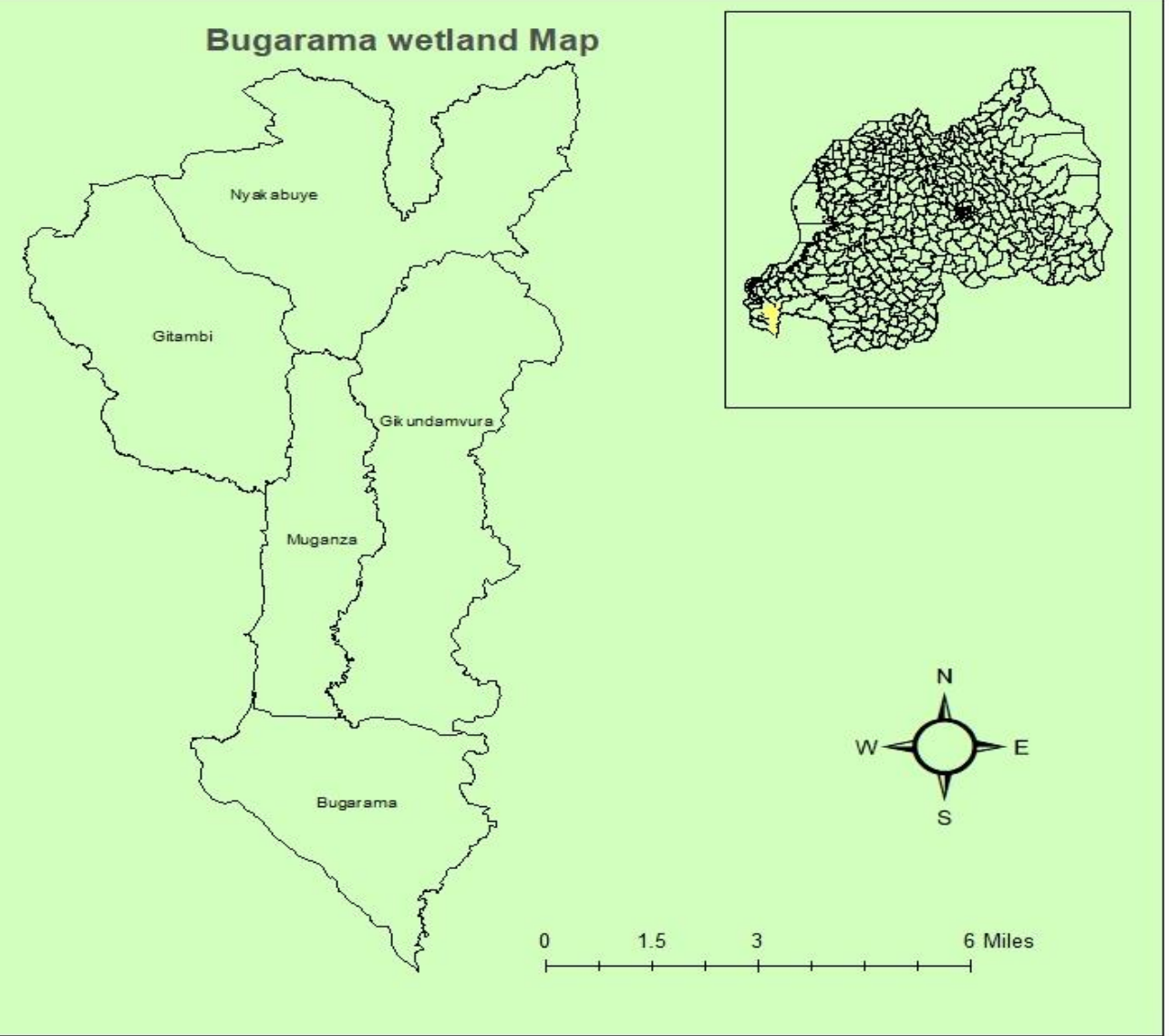




\section{Data Collection and Sampling Procedures}

The research employed survey method to collect data from households by the use of structured questionnaires. We purposively selected Bugarama marshland among other rice production schemes in Rwanda due to climatic vulnerability and high reduction in water level in the marshland (Shumbusho, 2009). This research employed Yamane's (1967) method to approximate the sample size of the study from the rice farmers population.

$$
n=\frac{N}{1+N e^{2}}
$$

The method of sampling was considered appropriate because the study systematically randomized the selection of respondents from different villages within Bugarama wetland. Notably, this study employed stratification to categorize farmers with respect to their location. The selected respondents per strata depended on the number of farmers within the villages in the stratas and the scale of rice production. 300 farmers' households were sampled.

\section{Data Analysis}

The data obtained from farmers' households was descriptively analyzed and then ran through the Heckman two-step sample selection method for STATA-14.0, SPSS-20.0 and Microsoft Excel software 2016. The descriptive statistics described the adaptation methods used by farmers to increase rice yields in the midst of changing climate and its effect. We decided to use Heckman two-step selection method to analyze the researched data. This procedurally determined the choices adopted by farmers to maximize their yield by the use of emergent technology (Heckman, 1979). The steps require more than one model to realize two regressions that appropriately correct selection bias during the process of decision-making on the preferred choice. Heckman's models are based on the farmer's utility, behaviours and knowledge to adopt new technology that maximizes the yields. It is assumed that farmers perceive the utilization of new technology to be better than the old methods for profit maximization (Asrat \& Simane, 2018).
The Heckman method considers options of perception. Either farmers perceived climate change or do not for the selection model. The outcome model explored whether the farmers adopted a method of adaptation relying on the condition in stage one. During the two processes, it was likely that the respondents to the perception of climatic change did not necessarily respond to adaptation method choice. This would then cause sample bias (Asrat \& Simane, 2018). This selection bias is likely to be corrected by the two-step procedural maximum likelihood that underlay the association between the variables as shown in the equation below:

$y_{j}=x_{j} \beta+u_{1 j}$

Therefore, the only observed binary outcome was given by probit model as:

$$
y_{j}^{\text {probit }}=(y>0)
$$

Lastly, the dependent variable is observed only if $j$ is in the selection as:

$$
\begin{aligned}
& y_{j}^{\text {probit }}=Z_{j} \delta+u_{2 j}>0 \\
& u_{1 j} \sim N(0,1) \\
& u_{2 j} \sim N(0,1) \\
& \operatorname{corr}\left(u_{1}, u_{2} \sim N(0,1)=\rho\right.
\end{aligned}
$$

Where; $y_{j}^{\text {probit }}$ is the perception when there is climate change or not, $Z$ is a coefficient vector that was hypothesized; $\delta$ is the variable estimates; $u_{1}, u_{2}$ are terms of error. According to Asrat and Simane (2018) when $(\rho \neq 0)$, the standard probit give biased results. Therefore, outcome and the selection models are correlated and consistently yield by coefficient estimates for all variable. Equation (3) is the stage one of Heckman's twostep model and Equation (1) is for outcome model that determines the choice of adaptations strategy by farmers from the knowledge of perception on climate change.

We used perception as the dependent variable for selection and adaptation for the outcome equation 
model. The variables are dummy variables that are in correlation with the Heckman assumption (Asrat \& Simane, 2018; Heckman, 1979). The independent variables that explained Bugarama farmers' perceptions and adaptation choices included characteristics of households, environmental issues and new technology options as selected by hypothesized association of variables.

\section{RESULTS AND DISCUSSION}

\section{Farmers' adaptation methods at Bugarama wetland}

The adaptation methods that were surveyed from the field were described and ranked descriptively by percentages. The descriptive statistics from the results showed that all farmers perceived and adapted to climate change in different ways. Most of the farmers adopted the integration of crops and livestock $(12.0 \%)$ to supplement rice yields during adverse climatic conditions. The most adopted methods of adaption to increase yield are supplementary irrigation (10.8\%), use of shallows for water irrigation (11.1\%), water conservation through mulching $(5.8 \%)$, planting of improved rice crop (9.2\%) and the intensification of pest control $(11.6 \%)$ due to emergence of diseases in crops. Moreover, farmers adapted to climate change in various ways at Bugarama that includes seeking for early warning information (4.9\%), shifting planting dates $(5.9 \%)$, diversifying to other businesses during loss $(3.9 \%)$, avoiding flood-prone areas (6.9\%), insuring farms against risk $(0.8 \%)$ and receiving compensation $(0.5 \%)$ from cooperatives. Most of the adaptation methods adopted by the farmers from Bugarama rice production were also identified in other studies (Ansari et al., 2018; Hamza \& Iyela, 2012; Mase et al., 2017; Mase et al., 2017; Moshi \& Isinika, 2016; Omondi et al., 2014; Phinzi et al., 2019; Teklewold et al., 2019). The methods are as shown in Figure 2.

Figure 2 Methods used by Bugarama rice farmers

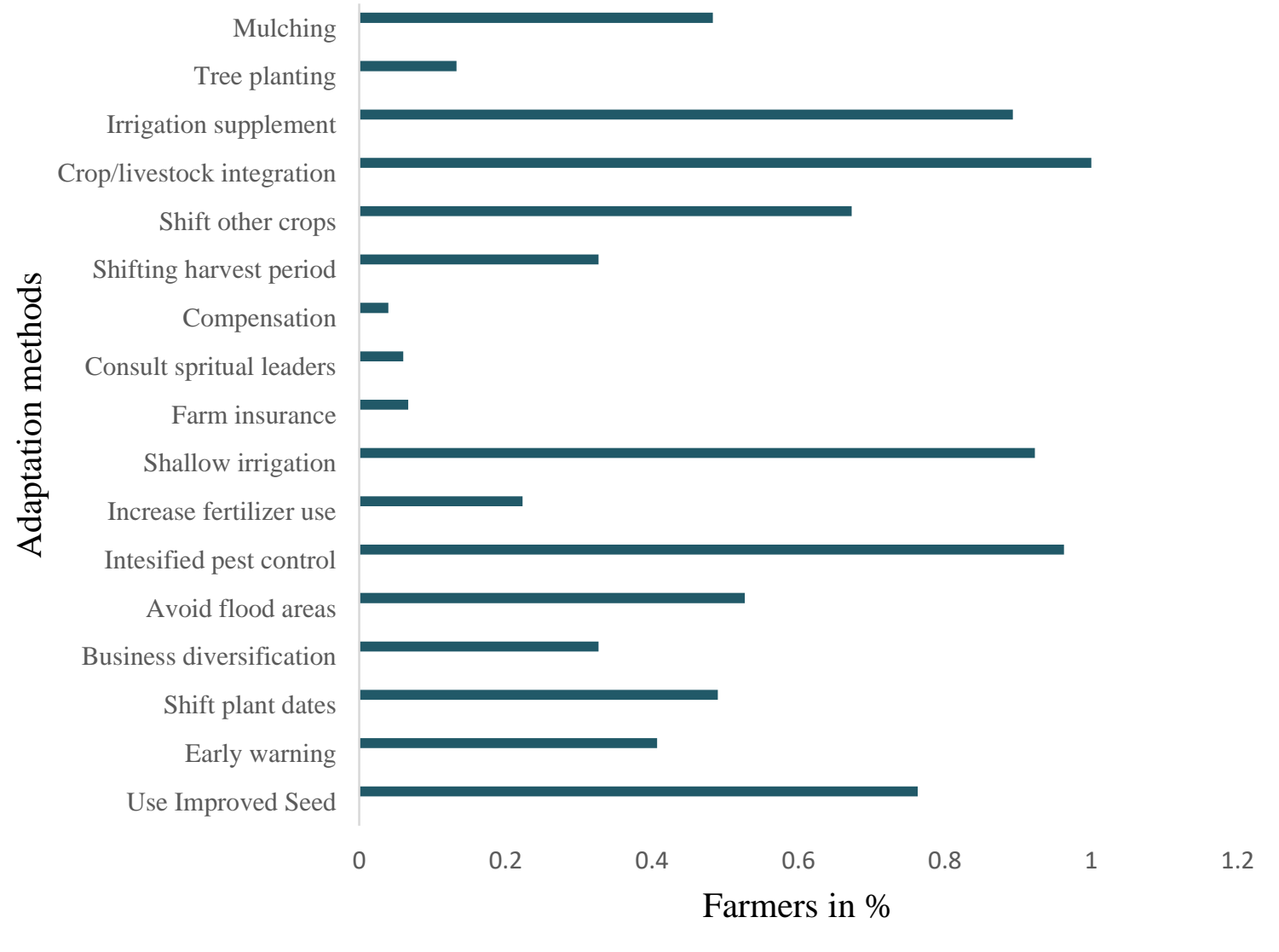


East African Journal of Agriculture and Biotechnology, Volume 2, Issue 1, 2020

Article DOI: https://doi.org/10.37284/eajab.2.1.137

\section{Factors influencing adaptation methods}

Table 1 shows the descriptive statistic of explanatory variables that are used to define the determinants of adaptation methods adopted by the rice farmers of Bugarama. $77.7 \%$ of farmers in Bugarama perceived climate change as affecting their rice yields thus $76.7 \%$ of the farmers responded that they apply adaptation methods to increase the rice yield in the midst of climate change effects. As the Heckman model procedure, we decided to underline factors that influence farmers' perception about climate as age, gender, level of education, extension access and training, effects of climate change on rice yield and frequent of catastrophes like droughts and floods. We determined factors that affect adaptation methods employed by farmers such as Household characteristics and farm income that includes offfarm income, information access, cooperative influence, farmers experience, employment status, rice income and other factors (Berhanu \& Beyene, 2015; Ferdushi et al., 2019). A summary of the influencing factors has been recorded in Table 1 and Table 2.

Table 1: Descriptive statistics of Heckman model variables

\begin{tabular}{|c|c|c|c|c|}
\hline Variable & Mean & Std. Dev. & Min & Max \\
\hline Perception & .253 & .701 & 0 & 1 \\
\hline Adapted & .233 & .424 & 0 & 1 \\
\hline Age & 41.2 & 9.24 & 23 & 71 \\
\hline Gender & .626 & .485 & 0 & 1 \\
\hline Marital status & .323 & .469 & 0 & 1 \\
\hline Level of Education & 2.33 & .823 & 1 & 4 \\
\hline Household size & 4.03 & 1.804 & 1 & 8 \\
\hline Credit access & .623 & .485 & 0 & 1 \\
\hline Extension access & .873 & .333 & 0 & 1 \\
\hline Info from other farmers & .953 & .211 & 0 & 1 \\
\hline Access to market & .967 & .179 & 1 & 5 \\
\hline Market Distance & 3.10 & .842 & 1 & 5 \\
\hline Rice income & 237.2 & 141.8 & 5.38 & 660.64 \\
\hline Farm size & 1.599 & 1.017 & .2 & 5.0 \\
\hline Climate awareness & 3.79 & .852 & 1 & 5 \\
\hline Climate effects & 3.52 & .955 & 1 & 5 \\
\hline Invasion by Pest & 1.53 & .5 & 1 & 2 \\
\hline Farmers' experience & 8.86 & 7.05 & 1 & 35 \\
\hline Water level & 3.11 & 1.06 & 1 & 5 \\
\hline
\end{tabular}

Table 2: Results of the Heckman probit selection model for Bugarama Rice production

\begin{tabular}{|c|c|c|c|c|c|c|c|c|}
\hline \multirow{3}{*}{ Variable } & \multicolumn{4}{|l|}{ Regression } & \multicolumn{4}{|c|}{ Marginal effects } \\
\hline & \multicolumn{2}{|c|}{ Perception (Selection) } & \multicolumn{2}{|c|}{ Adapted (Outcome) } & \multicolumn{2}{|c|}{ Perception (Selection) } & \multicolumn{2}{|c|}{ Adapted (Outcome) } \\
\hline & Coefficient & $P$ value & Coefficient & $P$ value & $\mathrm{dy} / \mathrm{dx}$ & $P$ value & $\mathrm{dy} / \mathrm{dx}$ & $P$ value \\
\hline Age & -0.002 & 0.677 & 0.009 & 0.327 & -0.037 & 0.15 & 0.002 & 0.524 \\
\hline Gender & 0.088 & 0.382 & -0.145 & 0.448 & 0.003 & 0.946 & -0.046 & 0.385 \\
\hline Level of education & -0.072 & 0.196 & 0.069 & 0.54 & $-0.073 * *$ & 0.019 & 0.021 & 0.486 \\
\hline Extension access & 0.144 & 0.443 & $-1.226 * * *$ & 0.000 & $0.151 * * *$ & 0.001 & $-0.472 * * *$ & 0.000 \\
\hline Level of water & -0.03 & 0.231 & 0.109 & 0.237 & -0.037 & 0.113 & 0.03 & 0.229 \\
\hline Marital status & -0.123 & 0.347 & -0.126 & 0.535 & -0.035 & 0.466 & -0.033 & 0.532 \\
\hline Household size & 0.029 & 0.926 & 0.075 & 0.162 & 0.019 & 0.135 & $0.023^{*}$ & 0.098 \\
\hline Farm size & 0.005 & 0.251 & -0.113 & 0.247 & -0.01 & 0.673 & -0.031 & 0.242 \\
\hline Market Distance & 0.122 & 0.074 & $-0.301 * *$ & 0.036 & $0.105^{* * *}$ & 0.002 & $-0.078 * *$ & 0.047 \\
\hline Credit access & $0.192 *$ & 0.017 & -0.094 & 0.65 & 0.022 & 0.678 & 0.035 & 0.54 \\
\hline Access to market & -0.248 & 0.665 & -0.280 & 0.518 & -0.098 & 0.513 & -0.08 & 0.567 \\
\hline Rice income & 0.0005 & 0.288 & $0.003 * * *$ & 0.000 & $0.155 * * *$ & 0.000 & $0.782 * *$ & 0.032 \\
\hline Aware of climate & & & -0.01 & 0.928 & & & 0.017 & 0.581 \\
\hline Effect of climate & & & $0.212 * *$ & 0.043 & & & $0.058 * *$ & 0.038 \\
\hline
\end{tabular}


East African Journal of Agriculture and Biotechnology, Volume 2, Issue 1, 2020

Article DOI: https://doi.org/10.37284/eajab.2.1.137

\begin{tabular}{|c|c|c|c|c|c|c|c|c|}
\hline \multirow{3}{*}{ Variable } & \multicolumn{4}{|l|}{ Regression } & \multicolumn{4}{|c|}{ Marginal effects } \\
\hline & \multicolumn{2}{|c|}{ Perception (Selection) } & \multicolumn{2}{|c|}{ Adapted (Outcome) } & \multicolumn{2}{|c|}{ Perception (Selection) } & \multicolumn{2}{|c|}{ Adapted (Outcome) } \\
\hline & Coefficient & $P$ value & Coefficient & $P$ value & $\mathrm{dy} / \mathrm{dx}$ & $P$ value & $\mathrm{dy} / \mathrm{dx}$ & $P$ value \\
\hline Invasion pest & & & -0.083 & 0.305 & & & -0.019 & 0.37 \\
\hline Farmers' experience & & & -0.0003 & 0.984 & & & 0.0005 & 0.886 \\
\hline Other farmers' info. & & & $5.996 * * *$ & 0.001 & & & $0.233 * * *$ & 0.000 \\
\hline lambda & -0.102 & 0.590 & & & & & & \\
\hline Constant & $\begin{array}{l}0.189 \\
(0.437)\end{array}$ & & $\begin{array}{l}-0.472 \\
(1.170)\end{array}$ & & & & & \\
\hline
\end{tabular}

Note: $* * * p<0.01 * * p<0.05 * \mathrm{p}<0.1$ for significant levels

The results from the outcome regression model in Table 2 showed that the effects of climate change on rice farming was positively correlated to the farmers 'choice of adaptation method against climate change to improve their yields at $(\mathrm{p}<0.05)$ which would increase the use of new strategies by $5.8 \%$ in Bugarama wetland rice production. There was a negative and weak correlation between farmers' awareness and choice of adaptation. However, this correlation was not statistically significant $(p>0.05)$. These findings are in contrast with sentiments expressed by Adego et al., (2019) and Omondi et al., (2014) who claimed that the knowledge and awareness of climate change had a positive and significant influence on the choice of adaptation by farmers. There was a negative relationship between pest invasion and farmers' choice of adaptation, this would influence the choice of adaptation by $1.9 \%$ which was not significant. The same results were also supported by Onyeneke (2019) that the farmers' choice of adaptation was influenced by pest invasion which is a critical determinant of controlling pest and disease epidemics.

The age of a farmer at Bugarama had a weak and negative influence on farmer's perception about climate change, $(\mathrm{p}>0.05)$, which was not significant. Similarly, with regards to the influence of age on adaptation choice, $(p>0.05)$, it was found that age was not statistically influencing adaptation though there was a probability of $0.2 \%$ influence on farmers' choice of adaptation. Mabuku et al., (2019) reported that experience in farming influences the adaptation option though was not significant. The same results were posited by this study where farmers' experiences would increase the probability of adaptation choice by $0.05 \%$ only. Thus, this revealed that regardless of the age or experience farmers would perceive climate change and make choices on adaptation options at Bugarama wetland.

The results showed that there was a positive association between gender and the perceptions though there was no statistical significance. Gender (male or female) did not necessarily affect the farmer's perception nor the choice of adaptation method against climate change effects. However, these findings were contrary to those found in other studies (Amare \& Simane, 2017; Mabuku et al., 2019; Moroda et al., 2018). The same results as the gender of this study were reported by the marital status which showed that whether married or single would not make a farmer perceive climate change or adapt against its effects.

As from other studies around the world, farm income makes farmers perceive climate change and decide on adaptation method to curb climate change effects on their farm (Alemayehu \& Bewket, 2017; Moroda et al., 2018; Ojo \& Baiyegunhi, 2019). Rice income was highly positive and statistically significant to make Bugarama farmers decide on the adaptation choices $(\mathrm{p}<0.001)$. Moreover, rice income would increase farmers' perception by $15.5 \%$ and adapt to climate change by $78.2 \%$. Therefore, there was a high probability that farmers adapt to climate change effects to utilize the best methods to improve yields and make more income as reported by Mikémina, (2013). Notably, there was neither a significant relationship between farm size and perception nor adaptation method chosen by Bugarama farmers. However, this result was contrary to those posted by Belay et al., (2017) and Enete, (2013) who reported that firm size had a statistically significant influence on the adaptation methods employed by farmers.

With regards to the farmers' level of education, it can be seen that there was a negative relationship to 
perceptions about climate change, though not significant ( $p$ >0.05). However, there was a probability of $7.3 \%$ to increase in the farmers' perception of climate change. On the other hand, there was no significant association between the level of education and the adaptation strategies chosen by farmers of Bugarama wetland to mitigate climate change effects. These findings showed that the level of education did not affect the choice of adaptation options against climate change. Therefore, in Bugarama rice scheme, all farmers had the same opportunities to adapt. (Deressa et al., 2009; Onyekuru \& Marchant, 2016) also reported that farmers' level of education was statistically associated with the farmer's adaptation which was in contrast to this study.

The number of individuals in the household was not statistically significant at $(\mathrm{p}<0.05)$. However, the results showed that the household size would increase the probability of adaptation by $2.3 \%$. Therefore, results showed that some farmers would adopt the best adaptation options to improve income for their households. The findings were similar to those reported by Ali and Erenstein, (2017), who stated that family size had a statistically significant influence on the adaption of measures to combat the constraints caused by environmental degradation and climate change effects.

According to this study, credit access influence perception about climate change at $(\mathrm{p}<0.1)$, it was correlating to adaptation methods applied by Bugarama farmers. This was in line with studies such as (Deressa et al., 2009; Shongwe et al., 2014) who implied that access to loan and credit necessarily influence the adaptation option by farmer even though Bugarama farmers mainly depend on cooperative assistance and guidance to improve their productivity as reported Barayandema et al., (2017).

This study found that extension access at Bugarama was key to rice farmers. Credit access influenced farmers' perception though was not significance at $(\mathrm{p}<0.05)$ and access to credit had a probability of influencing perception by $15.1 \%$ at $p<0.01$. It also noticed that there was a negative and significant influence of credit access to adaptation option at $\mathrm{p}$ $<0.01$. Moreover, this had a probability of $47.2 \%$ to make choice on new adaptation strategies. Thereby, access to farm inputs such as seeds, fertilizers, machinery and training services increase the probability of adapting. Bugarama farmers were subsidized by cooperatives to access extension services. The same results were reported by (Mulwa et al., 2017; Shongwe et al., 2014) who reported that due to the subsidies by cooperatives, extension services were found to have a statistically significant influence on the farmer's decision to adapt to climate change methods. Similar sentiments were also expressed by Ali and Erenstein (2017) who reported that when farmers have access to extension, they tend to adopt alternative methods.

Access to market was neither significantly influencing farmers' perception nor the choice of adaptation since all Bugarama farmers had ready market in the cooperatives (Barayandema et al., 2017). However, market distance had a probability of $10.5 \%$ influence to farmers' perceptions. Moreover, farmers' choice of adaptation was negatively and statistically determined by market distance at $(\mathrm{p}<0.05)$ and had a probability of $7.8 \%$ to decrease the choice of adaptation methods However, there have been mixed results on the market distance as reported by Adego et al. (2019), Khanal et al. (2018) and Moshi and Isinika (2016).

Farmers to farmers contact was statistically significant and influenced the farmers' adaptation choices at $(p<0.001)$ which showed a positive association, and this had a probability of increasing farmers' decision making by $23.3 \%$ on new adaptation method against climate change. Alemayehu and Bewket (2017) and Khatri-Chhetri et al. (2017) posited that, it is easier to access information from other farmers was for the new adaptation methods. Lastly, this study reports that, the wetland water level did not influence perception about climate change or making a choice on the adaptation methods against climate change.

\section{CONCLUSION}

The choice of adaptation to climate change requires two steps to make a concrete choice so as to respond to the changing climate. These are perception followed by decision-making. This study decided to use Heckman two-step sample selection model to 
determine factors that influence the choice of adaptation options. It was found that farmers perceive the changing climate and make a decision to survive by implementing adaptation strategies.

The study concluded that, farmers of Bugarama significantly perceive climate change due to its effects on the rice production, rice income and extension access from cooperatives. These were factors that were found to have a significant probability of influence on farmers' decision for adaptation strategies.

Sensitively, the government of Rwanda needs to formulate enabling policies that allow access to facilities such as fertilizers and pest controls. There should be adequate infrastructural development that pursue the reduction of input costs by Bugarama rice farmers and also provides informational services through cooperative agents. The government should also provide subsidies to farm inputs like fertilizers. Finally, our study in Bugarama wetland may be suitable for other areas in Rwanda and other parts of the world which are vulnerable to climate change effects.

\section{RECOMMENDATION AND POLICY IMPLICATION}

Rwanda Ministry of Agriculture needs to come up with participatory programs that take care of the farmers' access to information facilities on new adaptive technologies in order to develop a practical farmer-centered intervention strategy with the aim of positive perceptions towards rice farming in the country.

\section{ACKNOWLEDGMENTS}

We would like to thank Bugarama wetland farmers and their families for the useful information and the academy project from European Union for financing the research. We would also like to acknowledge the agricultural cooperatives and the local administrators for assistance during the study period. We are also grateful to Kenyatta University professors from the Environmental Department for providing guidance during this research study. Finally, we would like to thank Fred Adick for his technical assistance.

\section{REFERENCES}

Adego, T., Simane, B., \& Woldie, G. A. (2019). The impact of adaptation practices on crop productivity in northwest Ethiopia: an endogenous switching estimation. Development Studies Research, 6(1), 129-141. https://doi.org/10.1080/21665095.2019.167818 6

Alemayehu, A., \& Bewket, W. (2017). Determinants of smallholder farmers' choice of coping and adaptation strategies to climate change and variability in the central highlands of Ethiopia. Environmental Development, 24, 77-85. https://doi.org/10.1016/J.ENVDEV.2017.06.00 6

Ali, A., \& Erenstein, O. (2017). Assessing farmer use of climate change adaptation practices and impacts on food security and poverty in Pakistan. Climate Risk Management, 16. https://doi.org/10.1016/j.crm.2016.12.001

Amare, A., \& Simane, B. (2017). Determinants of smallholder farmers' decision to adopt adaptation options to climate change and variability in the Muger Sub basin of the Upper Blue Nile basin of Ethiopia. Agriculture and Food Security, 6(1). https://doi.org/10.1186/s40066-017-0144-2

Ansari, M. A., Joshi, S., \& Raghuvanshi, R. (2018). Understanding farmers perceptions about climate change: a study in a North Indian State, 1, 85-89. https://doi.org/10.30881/aaeoa.00015

Asrat, P., \& Simane, B. (2018). Farmers' perception of climate change and adaptation strategies in the Dabus.

Barayandema, J., Manzi, O., \& Umuhoza, G. (2017). Rice farming and income distribution along the value chain in, 7(3).

Belay, A., Recha, J. W., Woldeamanuel, T., \& Morton, J. F. (2017). Smallholder farmers' adaptation to climate change and determinants of their adaptation decisions in the Central Rift Valley of Ethiopia. Agriculture and Food Security, 6(1). https://doi.org/10.1186/s40066017-0100-1 
Berhanu, W., \& Beyene, F. (2015). Climate variability and household adaptation strategies in southern Ethiopia. Sustainability (Switzerland), 7(6). https://doi.org/10.3390/su7066353

Celia Reyes, Joel Bancolita, N. L. L. and S. J. C. (2014). Impacts of Climate Change on Household Food Security in the Philippines, (December 2014), 1-106.

Deressa, T. T., Hassan, R. M., Ringler, C., Alemu, T., \& Yesuf, M. (2009). Determinants of farmers' choice of adaptation methods to climate change in the Nile Basin of Ethiopia. Global Environmental Change, 19(2), 248-255. https://doi.org/10.1016/j.gloenvcha.2009.01.00 2

Enete, A. A. (2013). Challenges of agricultural adaptation to climate change: The case of cassava post-harvest in Southeast Nigeria. International Journal of Climate Change Strategies and Management. https://doi.org/10.1108/IJCCSM-08-2012-0045

Ferdushi, Ismail, \& Kamil. (2019). Perceptions, Knowledge and Adaptation About Climate Change: A Study on Farmers of Haor Areas After a Flash Flood in Bangladesh. Climate, 7(7), 85. https://doi.org/10.3390/cli7070085

Garcia, O. A. (2015). Republic of Rwanda Support Project for the Strategic Plan for the Transformation of Agriculture PROJECT PERFORMANCE ASSESSMENT, (March).

Gupta, A. K., Negi, M., Nandy, S., Alatalo, J. M., Singh, V., \& Pandey, R. (2019). Assessing the vulnerability of socio-environmental systems to climate change along an altitude gradient in the Indian Himalayas Assessing the vulnerability of socio-environmental systems to climate change along an altitude gradient in the Indian Himalayas. Ecological Indicators, 106(July), 105512.

https://doi.org/10.1016/j.ecolind.2019.105512

Hamza, I., \& Iyela, A. (2012). Land Use Pattern, Climate Change, and Its Implication for Food Security in Ethiopia: A Review. Ethiopian Journal of Environmental Studies and
Management,

5(1).

https://doi.org/10.4314/ejesm.v5i1.4

Heckman, J. J. (1979). The Common Structure of Statistical Models of Truncation, Sample Selection and Limited Dependent Variables and a Simple Estimator for Such Models, 475-492. Retrieved from https://econpapers.repec.org/RePEc:nbr:nberch: 10491\#.XezoVOAAIk8.mendeley

Kabubo-mariara, J. (2006). The Economic Impact of Climate Change on Kenyan Crop Agriculture: A Ricardian Approach *.

Khanal, U., Wilson, C., Lee, B. L., \& Hoang, V. N. (2018). Climate change adaptation strategies and food productivity in Nepal: a counterfactual analysis. Climatic Change. https://doi.org/10.1007/s10584-018-2214-2

Khatri-Chhetri, A., Aggarwal, P. K., Joshi, P. K., \& Vyas, S. (2017). Farmers' prioritization of climate-smart agriculture (CSA) technologies. Agricultural Systems, 151, 184-191. https://doi.org/10.1016/j.agsy.2016.10.005

Lamboll, R., Stathers, T., \& Morton, J. (2017). Climate Change and Agricultural Systems. In Agricultural Systems: Agroecology and Rural Innovation for Development: Second Edition. https://doi.org/10.1016/B978-0-12-8020708.00013-X

Mabuku, M. P., Senzanje, A., Mudhara, M., Jewitt, G. P. W., \& Mulwafu, W. O. (2019). Strategies for coping and adapting to flooding and their determinants: A comparative study of cases from Namibia and Zambia. Physics and Chemistry of the Earth, Parts A/B/C, 111, 2034. https://doi.org/10.1016/J.PCE.2018.12.009

Mase, A. S., Gramig, B. M., \& Prokopy, L. S. (2017). Climate change beliefs, risk perceptions, and adaptation behavior among Midwestern U.S. crop farmers. Climate Risk Management, 15, 8-17. https://doi.org/10.1016/j.crm.2016.11.004

Mashizha, T. M. (2019). Adapting to climate change: Reflections of peasant farmers in Mashonaland West Province of Zimbabwe. 
Jàmbá Journal of Disaster Risk Studies, 11(1), 1-8. https://doi.org/10.4102/jamba.v11i1.571

Mikémina, P. (2013). Climate Change Impact on Togo's Agriculture Performance: A Ricardian Analysis Based on Time Series Data. Ethiopian Journal of Environmental Studies and Management.

https://doi.org/10.4314/ejesm.v6i4.7

Mikova, K., Makupa, E., \& Kayumba, J. (2015). Effect of Climate Change on Crop Production in Rwanda, 4(3), 120-128. https://doi.org/10.11648/j.earth.20150403.15

Moroda, G. T., Tolossa, D., \& Semie, N. (2018). Perception and adaptation strategies of rural people against the adverse effects of climate variability: A case study of Boset District, East Shewa, Ethiopia. Environmental Development, 27 , 2-13. https://doi.org/10.1016/J.ENVDEV.2018.07.00 5

Moshi, A., \& Isinika, A. (2016). Climate Variability and Farm Technology Adoption Decisions among Smallholder Farmers in Pangani River Basin. Journal of Economics and Sustainable Development, 7(2), 18-24.

Mulwa, C., Marenya, P., Rahut, D. B., \& Kassie, M. (2017). Response to climate risks among smallholder farmers in Malawi: A multivariate probit assessment of the role of information, household demographics, and farm characteristics. Climate Risk Management, 16, 208-221.

https://doi.org/10.1016/j.crm.2017.01.002

Ojo, T. O., \& Baiyegunhi, L. J. S. (2019). Determinants of climate change adaptation strategies and its impact on the net farm income of rice farmers in south-west Nigeria. Land Use Policy, 103946. https://doi.org/10.1016/J.LANDUSEPOL.2019. 04.007

Omondi, P. A. o., Awange, J. L., Forootan, E., Ogallo, L. A., Barakiza, R., Girmaw, G. B., ... Komutunga, E. (2014). Changes in temperature and precipitation extremes over the Greater Horn of Africa region from 1961 to 2010.
International Journal of Climatology, 34(4), 1262-1277. https://doi.org/10.1002/joc.3763

Onyekuru, N. A., \& Marchant, R. (2016). Assessing the economic impact of climate change on forest resource use in Nigeria: A Ricardian approach. Agricultural and Forest Meteorology, 220, 1020.

https://doi.org/10.1016/J.AGRFORMET.2016. 01.001

Onyeneke, R. U. (2019). Does climate change adaptation lead to increased productivity of rice production? Lessons from Ebonyi State, Nigeria. Renewable Agriculture and Food Systems. https://doi.org/10.1017/S1742170519000486

Phinzi, K., Silas, N., Weitz, N., Carlsen, H., Skånberg, K., Dzebo, A., ... Johnson, O. W. (2019). SDGs and the environment in the EU: A systems view to improve coherence. International Soil and Water Conservation Research, 26(1), 27-46. https://doi.org/10.1007/s10784-019-09441-y

Shongwe, P., Masuku, M. B., \& Manyatsi, A. M. (2014). Factors Influencing the Choice of Climate Change Adaptation Strategies by Households: A Case of Mpolonjeni Area Development Programme (ADP) in Swaziland. Journal of Agricultural Studies, 2(1), 86. https://doi.org/10.5296/jas.v2i1.4890

Shumbusho. (2009). wetland management and sustainable in Rwanda, (March).

Teklewold, H., Mekonnen, A., \& Kohlin, G. (2019). Climate change adaptation: a study of multiple climate-smart practices in the Nile Basin of Ethiopia. Climate and Development, 11(2), 180192. https://doi.org/10.1080/17565529.2018.144280 1

Yamane, T. (1967). Statistics: an introductory analysis - 2nd ed. New York: Harper and Row. Retrieved from https://www.worldcat.org/title/statistics-anintroductory-analysis-2nded/oclc/299725866\#.XfEk4h7Uh4k.mendeley 